\title{
PENGGUNAAN MEDIA PUZZLE UNTUK MENINGKATKAN KEMAMPUAN MENGENAL BENTUK GEOMETRI
}

\author{
Elan ${ }^{1}$, Dindin Abdul Muiz L ${ }^{2}$, Feranis \\ ${ }^{1}$ Program Studi PGPAUD UPI Kampus Tasikmalaya \\ ${ }^{2}$ Program Studi PGSD UPI Kampus Tasikmalaya \\ ${ }^{3}$ Program Studi PGPAUD UPI Kampus Tasikmalaya
}

Email: elan@upi.edu

(Received: Mei 2017; Accepted: Mei 2017; Published: Juni 2017)

\begin{abstract}
The research was distributed by the importance of the ability to know the geometric shapes in learning in early childhood education. In a study in the OLD media, which used to use a simple media using paper and haven't been able to develop the ability to know the child in geometric shapes. This is shown by an indicator of the ability to know the geometric shapes are still low. To overcome this, the researchers select and use puzzle media didasari up studies of the literature that has been done. Formulation of the problem in this study generally lifting how the ability of teachers in designing a plan of learning through media puzzle and the ability of teachers in implementing the learning through media puzzle, increased ability to know the child in the form of geometry through the media puzzle. Whereas the aim of this research is generally to describe the ability of teachers in designing rencna learning through media puzzle and describes the ability of teachers in implementing the learning through media puzzle, increases the ability to know the child in the form of geometry through the media puzzle. The methods used in this research is a Research Collaborative Class Actions with the desian and research of Kemmis Taggard. The subject of this research is the child group B2 TK 1 Perwari Village sub district Tawang Town Tasikmalaya Tawangsari. Data collection techniques used are interviews, observation and documentation. The analysis of quantitative data using percentage and qualitative data using the Notes field. Based on the data obtained and the results of the analysis, it was concluded that the ability of teachers in designing plans and carry out learning the result very good, there is a progression of any action until I cycle cycle III. The ability to know the shape of the geometry by using the media puzzle better than each cycle I until the cycle III, compared with using media paper.
\end{abstract}

Keywords: The Ability To Know The Geometric Shapes, Puzzle Media 


\begin{abstract}
ABSTRAK
Penelitian ini dilatarbelakangi oleh pentingnya kemampuan mengenal bentuk geometri dalam pembelajaran di Pendidikan Anak Usia Dini. Dalam pembelajaran di PAUD, media yang digunakan menggunakan media sederhana menggunakan kertas (LKA) dan belum mampu mengembangkan kemampuan anak dalam mengenal bentuk geometri. Hal ini ditunjukkan dengan indikator kemampuan anak dalam mengenal bentuk geometri yang masih rendah. Untuk mengatasi hal tersebut, peneliti memilih dan menggunakan media puzzle yang didasri atas studi pustaka yang telah dilakukan. Rumusan masalah dalam penelitian ini secara umum mengangkat bagaimana kemampuan guru dalam merancang rencana pembelajaran melalui media puzzle dan kemampuan guru dalam melaksanakan pembelajaran melalui media puzzle, peningkatan kemampuan anak dalam mengenal bentuk geometri melalui media puzzle. Sedangkan tujuan dari penelitian ini secara umum untuk mendeskripsikan kemampuan guru dalam merancang rencna pembelajaran melalui media puzzle dan mendeskripsikan kemampuan guru dalam melaksanakan pembelajaran melalui media puzzle, meningkatkan kemampuan anak dalam mengenal bentuk geometri melalui media puzzle. Metode yang digunakan dalam penelitian ini adalah Penelitian Tindakan Kelas Kolaboratif dengan desian penelitian Kemmis dan Taggard. Subjek penelitian ini adalah anak kelompok B2 TK Perwari 1 Kelurahan Tawangsari Kecamatan Tawang Kota Tasikmalaya. Teknik pengumpulan data yang digunakan adalah wawancara, observasi dan dokumentasi. Analisis data kuantitatif menggunakan persentase dan data kualitatif menggunakan catatan lapangan.Berdasarkan data yang diperoleh dan hasil analisis, disimpulkan bahwa kemampuan guru dalam merancang rencana dan melaksanakan pembelajaran hasilnya sangat baik, ada perkembangan dari setiap tindakan siklus I sampai siklus III. Kemampuan anak dalam mengenal bentuk geometri dengan menggunakan media puzzle lebih baik dari setiap siklus I sampai siklus III, dibandingkan dengan menggunakan media kertas (LKA).
\end{abstract}

Kata Kunci :Kemampuan Mengenal Bentuk Geometri, Media Puzzle 


\section{PENDAHULUAN}

Dewasa ini penyelenggaraan anak usia dini harus sesuai dengan karakteristik perkembangan anak, sejak anak lahir sama usia 6 tahun. Permendikbud No 137 Tahun 2014 dalam standar isi, lingkup perkembangan anak yang menjelaskan bahwa

"Lingkup perkembangan sesuai tingkat usia anak meliputi aspek nilai agama dan moral, fisik motorik, kognitif, bahasa, sosial emosional, dan seni. Agar anak mencapai perkembangan yang optimal maka media pembelajaran yang dapat menarik minat dan motivasi belajar anak merupakan faktor yang menjadi peranan langsung dalam proses pembelajaran".

Dari kutipan di atas salah satu aspek pada anak usia dini adalah aspek perkembangan kognitif. Aspek perkembangan kognitif adalah aspek yang menciptakan pengetahuan dan gagasan anak tentang apa saja yang dilihat dan diketahui anak tentang lingkungan sekitar. Ini sejalan dengan pendapat dari Piaget (dalam Sujiono, 2013) yang menjelaskan bahwa "aspek kognitif merupakan suatu yang fundamental dan yang membimbing tingkah laku anak terletak pada pemahaman bagaimana pengetahuan tersebut terstruktur dalam berbagai aspek". Dalam aspek kognitif ada berbagai kemampuan meliputi pengetahuan dan kemampuan berpikir. Pengetahuan seperti sesuatu hal, benda dan ilmu yang dilihat oleh anak di lingkungan sekitar, sedangkan kemampuan berpikir seperti kemampuan logis matematik dalam hal mengenal bentuk geometri.

Kemampuan mengenal bentuk geometri di pendidikan anak usia dini (PAUD) sangat penting untuk dipelajari oleh anak. Sependapat dengan Sriningsih (2009) yang menjelaskan bahwa "bentuk geometri dapat dipelajari anak dengan mengenal bentuk - bentuk yang berhubungan dengan benda konkrit." Namun pada kenyataan di lapangan, pembelajaran matematika di PAUD tentang bentuk geometri pada kelompok B atau anak yang berusia 5 sampai 6 tahun hanya mengenal 4 bentuk geometri. Sedangkan Paths Toward (2009) yang menjelaskan bahwa "anak yang berumur 5 tahun sudah dapat mengenal bentuk persegi, persegi panjang, segitiga, lingkaran, jajar genjang, trapesium dan layang - layang".

Berdasarkan permasalahan diatas Pendidikan Anak Usia Dini (PAUD) dalam mencapai perkembangan anak yang optimal maka media pembelajaran yang digunakan oleh guru yang dapat menarik minat dan motivasi belajar anak untuk mencapai perkembangan yang ingin dicapai. Sriningsih (2009) yang menjelaskan bahwa

"Media dan sumber belajar merupakan faktor yang harus dipertimbangkan dalam merencanakan pembelajaran. Media dan sumber belajar yang dipilih harus sesuai dengan kegiatan dan dapat memberikan pengalaman yang cocok bagi anak. Guru juga harus memutuskan bagaimana media dan sumber belajar tersebut disediakan dan bagaimana kegiatan diorganisasikan".

Berdasarkan latar belakang masalah diatas peneliti tertarik untuk mengatasi permasalahan pembelajaran bentuk geometri yang kurang dan media yang digunakan kurang menunjang dilapangan. Dengan melakukan Penelitian Tindakan Kelas (PTK) kolaboratif dengan judul "Penggunaan Media Puzzle untuk Meningkatkan Kemampuan Mengenal Bentuk Geometri" yang dilaksanakan pada anak kelompok B di TK Perwari Kelurahan Tawangsari Kecamatan Tawang Kota Tasikmalaya.

Berlandaskan latar belakang masalah yang telah diuraikan oleh peneliti, rumusan masalah dalam penelitian ini adalah: 1) Bagaimana peningkatan kemampuan guru merencanakan pembelajaran dengan media puzzle untuk meningkatkan kemampuan mengenal bentuk geometri pada kelompok B di TK Perwari kelurahan Tawansari kecamatan Tawang kota Tasikmalaya?. 2) Bagaimana peningkatan kemampuan guru melaksanakan dengan media puzzle untuk meningkatkan kemampuan mengenal bentuk geometri pada kelompok B di TK Perwari kelurahan Tawansari kecamatan Tawang kota Tasikmalaya?. 3) Bagaimana 
peningkatan kemampuan anak dalam mengenal bentuk geometri melalui media puzzle di kelompok B di TK Perwari kelurahan Tawansari kecamatan Tawang kota Tasikmalaya?

Berangkat dari rumusan masalah di atas, tujuan penelitian ini adalah untuk: 1) Mendeskripsikan peningkatkan kemampuan guru dalam menyusun perencanaan pembelajaran harian untuk meningkatkan kemampuan mengenal bentuk geometri pada kelompok B di TK Perwari kelurahan Tawansari kecamatan Tawang kota Tasikmalaya. 2) Mendeskripsikan peningkatkan proses pelaksanaan pembelajaran yang dilaksanakan guru tentang media puzzle untuk meningkatkan kemampuan mengenal bentuk geometri pada kelompok B di TK Perwari kelurahan Tawansari kecamatan Tawang kota Tasikmalaya. 3) Meningkatan kemampuan anak dalam mengenal bentuk geometri melalui media puzzle di kelompok B di TK Perwari kelurahan Tawansari kecamatan Tawang kota Tasikmalaya.

secara teoritis yaitu dapat bermanfaat dalam pengembangan kemampuan mengenal bentuk geometri pada anak di Kelompok B TK Perwari kelurahan Tawansari kecamatan Tawang kota Tasikmalaya dan dapat meningkatkan motivasi belajar anak. Manfaat secara praktis bagi guru Memberikan informasi tentang pentingnya media puzzle dalam kegiatan pembelajaran dalam mengenal bentuk geometri untuk meningkatkan kemampuan mengenal bentuk geometri dan menjadi alternatif untuk media pembelajaran di sekolah. Bagi sekolah dapat dijadikan sebagai pengembangan untuk meningkatkan mutu pendidikan sekolah dapat meningkatkan mutu pendidikan di sekolah TK Perwari kelurahan Tawansari kecamatan Tawang kota Tasikmalaya, dapat menciptakan kerjasma yang baik antara kepa;a sekolah dengan guru dalam media dan metode yang digunakan dalam meningkatkan mutu pendidikan. Bagi anak memperoleh pengalaman bermain yang di belajarkan dan belajar yang menyenangkan yang mampu menginisiasi aspek - aspek perkembangan anak usia dini terutama pada aspek perkembangan kognitif.

\section{TINJAUAN PUSTAKA}

Matematika tidak dapat didefinisikan secara tepat dan pasti, seiring berjalannya waktu dan zaman yang sudah modern ini. Banyak beberapa definisi yang memiliki pandangan dan arti yang berbeda. Ini dapat dilihat berdasarkan paradigma dan perseftif yang beragam. Johnson dan Rising (dalam Sriningsih, 2009) yang menjelaskan bahwa "matematika merupakan pola berpikir, pola mengorganisasikan pembuktian yang logik, bahasa yang menggunakan istilah yang didefinisikan dengan cermat, jelas dan akurat, repertasinya dengan simbol dan padat, lebih berupa bahasa simbol mengenai ide (gagasan) daripada mengenai bunyi, pengetahuan struktur yang terorganisasikan sifat sifat atau teori - teori itu dibuat secara deduktif berdasarkan kepada unsur unsur yang didefinisikan atau tidak didefinisikan, aksioma - aksioma, sifat sifat, atau teori - teori yang telah dibuktikan kebenarannya, suatu seni, keindahannya terdapat pada keturutan dan keharmonisannya".

Dalam pembelajaran memiliki standar untuk mencapai tujuan pembelajaran, begitu juga dengan standar pembelajaran matematika yang memiliki standar pembelajaran untuk mencapai hasil belajar anak. NCTM (dalam Sriningsih, 2009) yang menjelaskan bahwa

"standar pembelajaran mengacu pada standar yang ditetapkan, yaitu:

1. Bilangan dan operasi bilangan (umber dan operation),

2. Aljabar (algebra),

3. Geometri (geometry),

4. Pengukuran (measurement),

5. Analisis data dan prababilitas (data analyisis and probability),

6. Pemecahan masalah (problem solving),

7. Penalaran dan pembuktian (reasoning and proof), 
8. Komunikasi (communications),

9. Koneksi (connections),

10. Representasi (representasion).

Dalam pembelajaran matematika untuk Anak Usia Dini guru membantu anak agar anak memiliki kebiasaan berfikir dengan jelas, beragumentasi, memiliki alasan dan pendapat dalam berkatifitas, menemukan cara atau alternatif lain dalam penyelesaian masalah dan membuat perkiraan.

Charlesworth dan Lind (dalamBeaty, 2013) menjelaskan "Bentuk geometri dua dimensi dasar meliputi lingkaran, segitiga, segi empat, dan persegi, tiap bentuk tersusun dari satu garis lurus." Konsep geometri bersifat abstrak, namun konsep tersebut dapat diwujudkan melalui cara semi konkret ataupun konkret. Bangun geometri terbagi menjadi dua yaitu bangun datar dan bangun ruang. Bangun ruang yaitu bangun yang mempunyai volume, contohnya adalah kubus, kerucut, tabung, bola, balok, dan lain-lain. Sedangkan bangun datar yaitu bangun geometri yang mempunyai sisi panjang dan luas, contohnya adalah segi empat, lingkaran, belah ketupat, persegi panjang, segi tiga, dan lain-lain. Dari beberapa definisi di atas dapat disimpulkan bahwa geometri merupakan suatu ilmu di dalam sistem matematika yang di dalamnya mempelajari garis, ruang, dan volume yang bersifat abstrak dan berkaitan satu sama lain, mempunyai garis dan titik sehingga menjadi sebuah simbol seperti bentuk persegi, segitiga, lingkaran, dan lain-lain.

Lestari, K.W (dalam Wahyu, 2014), yang menjelaskan bahwa "mengenal bentuk geometri pada anak usia dini adalah kemampuan anak mengenal, menunjuk, menyebutkan serta mengumpulkan bendabenda di sekitar berdasarkan bentuk geometri." Mengenal merupakan aspek yang sangat penting, karena salah satu tujuan kegiatan pembelajaran anak adalah anak mengenal apa yang telah dipelajari. Apabila dikaitankan dengan konsep - konsep geometri, guru dapat memulai dengan konsep bentuk geometri terlebih dahulu kepada anak. Pada saat guru menjelaskan tentang bentuk - bentuk geometri, sebaiknya guru selalu menggunakan media yang konkrit dan jelas dengan anak sehingga anak dapat melihat dan memanipulasi benda benda yang mempunyai bentuk geometri tersebut.

Standar geometri yang menjadi acuan untuk mengukur kemampuan geometri anak usia 1-12 tahun oleh National Council Of Teachers Mathematics (NCTM) (dalam Sriningsih, 2000, hlm.178), menjelaskan

"(1) Anak dapat mengenal bentuk geometri, (2) Anak dapat menyebutkan bentuk geometri, (3) Anak dapat menggambarkan suatu bentuk geometri, (4) Anak dapat membentuk geometri, (5) Anak dapat menyebutkan persamaan dan perbedaan dari 2 bentuk geometri atau lebih, (6) Anak dapat menguraikan bentuk geometri”.

Mukhtar Latif dkk. (2013) menjelaskan "media pembelajaran adalah segala sesuatu yang dapat dijadikan bahan (software) dan alat (hardware) untuk bermain yang membuat anak usia dini mampu memperoleh pengetahuan, keterampilan dan menentukan sikap". Jadi media pembelajaran adalah alat bantu untuk menunjang suatu proses pembelajaran agar pembelajaran menyenangkan. Media dalam sebuah proses pembelajaran dapat mempertinggi belajar anak dan juga dapat mempertinggi juga hasil belajar yang dicapai anak. Maka dari itu penggunaan media pada pembelajaran sangat dianjurkan untuk menjadikan kualitas pembelajaran yang tinggi.

Rokhmat (dalam Srianis, 2014) yang menyatakan, "Puzzle adalah permainan kontruksi melalui kegiatan memasang atau menjodohkan kotak-kotak, atau gambar bangun-bangun tertentu sehingga akhirnya membentuk sebuah pola tertentu." Berdasarkan pengertian diatas dapat disimpulkan bahwa media puzzle adalah alat peraga atau alat bantu untuk menunjang proses pembelajaran yang menggunakan puzzle dalam melaksanakan pembelajaran. Sedangkan media puzzlegeometri adalah alat peraga atau alat bantu untuk menunjang proses pembelajaran yang menggunakan kepingan - kepingan puzzle dengan bentuk geometri. 
Cara membuatnya buat pola untuk alas dan untuk kepingan puzzle. Pola untuk kepingan puzzle ditempel dengan gambar yang sesuai dengan tema kemudian dipotong sesuai dengan bentuk geometri seperti bentuk segitiga, segiempat, persegi panjang dan lingkaran. Lapisi potongan pola yang bawah dengan karton hitam. Buat puzzle sesuai dengan jumlah anak kemudian dibagi menjadi beberapa kelompok.

\section{METODE PENELITIAN}

Setting penelitian ini akan dilaksanakan di TK Perwari Kota Tasikmalaya. Subjek penelitian ini adalah guru kelompok B dan anak - anak kelompok B yang berjumlah 12 anak di TK Perwari kelurahan Tawangsari, kecamatan Tawang kota Tasikmalaya. Peneliti memilih model tindakan kelas (classroom action research), yang dikembangkan oleh Kemmis dan Mc Taggart.Sa'dun (2010) yang menjelaskan "model PTK yang dikembangkan oleh Kemmis dan Mc Taggart adalah model spiral yaitu pelaksanaan penelitian tindakan kelas meliputi perencanaan, tindakan dan observing (pengamatan), dan refleksi serta perbaikan rencana."Arikunto (2012) yang mengemukakan bahwa: "Pelaksanaan penelitian tindakan kelas merupakan sebuah proses yang terdiri dari: 1) perencanaan, 2) pelaksanaan dan pengamatan (observasi) dan 3) refleksi".

Pada penelitian ini menggunakan data primer dan data sekunder. Dimyati (2013) yang menjelaskan "Data primer diperoleh dari sumber data pertama. Dari subjek atau bjek penelitianlah data penelitian langsung diambil". Sumber data primer pada penelitian ini yaitu guru dan anak kelompok B TK Perwari 1 Kelurahan Tawangsari Kecamatan Tawang Kota Tasikmalaya.Dimyati (2013) yang menjelaskan bahwa "Data sekunder diambil dari pihak mana saja yang bisa memberikan tambahan data guna melengkapi kekurangan dari data yang diperoleh melalui sumber data". Pada data sekunder diambil dari data sebelumnya. Data sekunder diambil dari dokumentasi di TK Perwari 1 Kelurahan
Tawangsari Kecamatan Tawang Kota Tasikmalaya.

Instrumen penelitian merupakan alat penunjangan suatu peneitian. Penelitian ini adalah penelitian tindakan kelas jadi instrumen yang digunakan berupa Rencana Pelaksanaan Pembelajaran Harian (RPPH), Alat observasi seperti lembar penilaian guru dalam merencanakan pembelajaran, lembar penilaian guru dalam melaksanakan penelitian, lembar observasi guru dalam perencanaan, produk dan pelaksanaan media puzzle, Lembar observasi kemampuan anak dalam mengenal bentuk geometri, dan catatan lapangan.

Tehnik pengumpulan data meliputi, observasi, skala bertingkat dan dokumentasi. Pada penelitian ini memilih dua metode untuk mengumpulkan data yang digunakan untuk mengetahui kemampuan mengenal bentukbentuk geometri.

Analisis data kualitatif digunakan untuk menentukan peningkatan proses belajar khususnya berbagai tindakan yang dilakukan. Arikunto (2010) yang menjelaskan bahwa

"analisis data yang menggunakan teknik deskriptif kuantitatif memanfaatkan persentase yang merupakan langkah awal dari kesuluruhan proses analisis. Analisis kualitatif harus dinyatakan dalam sebuah predikat yang menunjuk pada kenyataan keadaan dan ukuran kualitas, seperti kurang sekali, kurang, cukup, baik, dan sangat baik".

Pengolahan dalam penelitian ini berupa data kuantitatif. Data hasil dari observasi guru dalam merencanakan, melaksanakan, merancang media dan melaksanakan dengan media. Catatan lapangan atau field note juga dapat menggunakan analisis data kualitatif.

Indikator keberhasilan dalam penelitian ini adalah ditandai dengan meningkatnya kemampuan mengenal bentukbentuk geometri pada anak harus mencapai sekurang - kurangnya $75 \%$. Guru mengalami peningkatan kemampuan dalam merancang rencana pembelajaran dan pelaksanaan pembelajaran khususnya dalam kegiatan pembelajaran peningkatan kemampuan 
mengenal bentuk geometri anak usia dini melalui media puzzle harus mencapi sekurang - kurangnya $75 \%$.

\section{HASIL PENELITIAN DAN PEMBAHASAN}

Penelitian ini dilaksanakan di kelompok $\mathrm{B}_{2}$ TK Perwari 1 dengan jumlah siswa 12 anak dan dilaksanakan dalam tiga siklus yaitu tindakan siklus I, tindakan siklus II dan tindakan siklus III. Pada setiap tindakan siklus dilakukan satu kali pertemuan dan dilakukannya refleksi dalam setiap siklusnya.

Peneliti akan mengetahui tahap awal anak dalam mengenal bentuk geometri. Berikut hasil dari prasiklus mengenai kemampuan anak dalam mengenal bentuk geometri pada kemampuan awal anak. Kemampuan awal ini dilaksanakan pada taggal 18 April 2017, pembelajaran menggunakan media lain yang menyakut pembelajaran dalam mengenal bentuk geometri.

Hasil kemampuan anak dalam mengenal bentuk geometri, secara keseluruhan yang didapat cukup baik karena hanya memperoleh nilai persentase $32,85 \%$ Seperti yang sudah dijelaskan bahwa persentase nilai yang kurang dari 60,1 \% dengan kriteria cukup baik. Pada prasiklus ini indikator pencapaiannya masih belum tercapai, karena kurang dari kriteria yang telah ditentukan, yaitu lebih dari $75 \%$.

Tabel 4.5

Rekapitulasi Aspek yang dicapai pada Tindakan siklus I

\begin{tabular}{lccc}
\hline Aspek & Jumlah & $\begin{array}{c}\text { Rata } \\
\text { - rata }\end{array}$ & Persentase \\
\hline $\begin{array}{l}\text { Menyebutkan } \\
\text { bentuk } \\
\text { geometri pada } \\
\text { media puzzle }\end{array}$ & 29 & 4,1 & $\mathbf{4 6 , 0 3 \%}$ \\
\hline $\begin{array}{l}\text { Menunjukan } \\
\text { bentuk } \\
\text { geometri pada } \\
\text { media puzzle }\end{array}$ & 27 & 3,8 & $\mathbf{4 7 , 6 2 \%}$ \\
\hline $\begin{array}{l}\text { Menyusun } \\
\text { kepingan puzzle } \\
\text { bentuk gemetri }\end{array}$ & & & \\
\hline $\begin{array}{l}\text { Menyebutkan } \\
\text { benda - benda } \\
\text { yang }\end{array}$ & 22 & 3,1 & $\mathbf{3 4 , 9 2 \%}$ \\
\hline
\end{tabular}

\begin{tabular}{l}
\hline menyerupai \\
bentuk \\
geometri yang \\
berada \\
dilingkungan \\
sekitar \\
\hline Menunjukan \\
benda - benda \\
yang \\
menyerupai \\
bentuk \\
geometri yang \\
berada \\
dilingkungan \\
sekitar
\end{tabular}

Dengan persentase nilai yang didapat yaitu pada aspek menyebutkan bentuk geometri pada media puzzle memperoleh persentase nilai 46,03\%. Pada aspek menunjukan bentuk geometri pada media puzzle memperoleh persentase nilai $47,62 \%$. Pada aspek menyusun kepingan puzzle bentuk gemetri memperoleh persentase nilai $41,37 \%$. Pada aspek menyebutkan benda - benda yang menyerupai bentuk geometri yang berada dilingkungan sekitar memperoleh persentase nilai $34,92 \%$. Dan untuk aspek menunjukan benda - benda yang menyerupai bentuk geometri yang berada dilingkungan sekitar memperoleh persentase nilai $39,79 \%$. Jadi aspek yang mencapai indikator pada tindakan siklus I tidak ada, untuk nilai persentase tertinggi dari 5 aspek adalah aspek menunjukan bentuk geometri pada media puzzle dengan persentase nilai $47,62 \%$. Persentase nilai lebih dari $75 \%$ untuk keterangan nilai sangat baik. Untuk nilai yang kurang dari $75 \%$ itu baik dan untuk nilai yang kurang dari 60,1\% itu cukup baik.

Refleksi terhadap kemampuan anak pada siklus I ini dititik beratkan pada kemampuan anak dalam mengenal bentuk geometri dengan menggunakan media puzzle. Setelah melalui proses analisis terhadap penguasaan keterampilan tersebut, anak masih belum mengetahui banyak bentuk geometri, rata rata anak hanya mengetahui 4 macam bentuk geometri yaitu bentuk segitiga, persegi, persegi panjang, dan lingkaran. Hal ini dapat 
dibuktikan dengan hasil kemampuan anak yang cukup berkembang. Pada saat melaksanakan recalling dan tanya jawab sebelum pulang hanya 3 anak yang berani menjawab bertanyaan dari guru, hal ini karena kurang komunikasi antara guru dan anak sehingga anak kurang dalam keaktifannya. Seharusnya guru lebih memfokuskan pada lembar instrumen yang akan di observasi aitu dalam mengenal bentuk geometri seperti bentuk segitiga, persegi panjang, persegi, lingkaran, trapesium, jajar genjang, dan layang - layang.

Tabel 4.15

Persentase Aspek yang dicapai pada Tindakan siklus II

\begin{tabular}{lccc}
\hline Aspek & Jumlah & $\begin{array}{c}\text { Rata } \\
\text { - rata }\end{array}$ & Persentase \\
\hline $\begin{array}{l}\text { Menyebutkan } \\
\text { bentuk geometri } \\
\text { pada media } \\
\text { puzzle }\end{array}$ & & 7,8 & $\mathbf{7 8 , 6 8 \%}$ \\
\hline $\begin{array}{l}\text { Menunjukan } \\
\text { bentuk geometri } \\
\text { pada media } \\
\text { puzzle }\end{array}$ & & & \\
\hline $\begin{array}{l}\text { Menyusun } \\
\text { kepingan puzzle } \\
\text { bentuk gemetri }\end{array}$ & & & \\
\hline $\begin{array}{l}\text { Menyebutkan } \\
\text { benda - benda } \\
\text { yang }\end{array}$ & & & \\
menyerupai \\
bentuk geometri \\
yang berada \\
dilingkungan \\
sekitar
\end{tabular}

persentase nilai dari aspek kemampuan anak dalam mengenal bentuk geometri pada tindakan siklus II di TK Perwari 1 Kota Tasikmalaya. Dengan persentase nilai yang didapat yaitu pada aspek menyebutkan bentuk geometri pada media puzzle memperoleh persentase nilai 78,68 \%. Pada aspek menunjukan bentuk geometri pada media puzzle memperoleh persentase nilai $68,60 \%$. Pada aspek menyusun kepingan puzzle bentuk gemetri memperoleh persentase nilai $60 \%$. Pada aspek menyebutkan benda - benda yang menyerupai bentuk geometri yang berada dilingkungan sekitar memperoleh persentase nilai $71,43 \%$. Dan untuk aspek menunjukan benda - benda yang menyerupai bentuk geometri yang berada dilingkungan sekitar memperoleh persentase nilai $71,43 \%$. Jadi aspek yang mencapai indikator pada tindakan siklus II tidak ada, untuk nilai persentase tertinggi dari 5 aspek di atas adalah aspek menyebutkan bentuk geometri pada media puzzle dengan persentase nilai 78,68 \%. Secara keseluruhan perkembangan aspek anak dalam mengenal bentuk geometri sudah sangat baik karena melebih kriteria yang telah ditentukan yaitu lebih dari $75 \%$ dari kreteria yang telah ditentukan. Nilai yang kurang dari $75 \%$ dengan kriteria nilai baik dan untuk nilai yang kurang dari 60,1\% dengan kriteria cukup baik.

Kemampuan anak pada siklus II ini sudah mulai berkembangan dengan baik, karena guru sudah mulai dekat dengan anak dan lebih banyak bercakap - cakap dengan anak. Masih sama seperti siklus I, pada siklus II juga menitikberatkan pada kemampuan anak dalam mengenal bentuk geometri dengan menggunakan media puzzle. Setelah melalui proses analisis terhadap penguasaan keterampilan tersebut, anak sudah mulai mengetahui bentuk samapi 6 bentuk ini terlihat dari anak muncul perkembangannya. Hal ini dapat dibuktikan dengan hasil kemampuan anak dalam mengenal bentuk geometri yang sudah berkembang dengan sangat baik.

Tabel 4.25

Persentase Aspek yang dicapai pada Tindakan siklus III

\begin{tabular}{lccc}
\hline Aspek & Jumlah & $\begin{array}{c}\text { Rata } \\
\text { - rata }\end{array}$ & Persentase \\
\hline $\begin{array}{l}\text { Menyebutkan } \\
\text { bentuk geometri } \\
\text { pada media }\end{array}$ & 55 & 7,8 & $\mathbf{9 8 , 2 1 \%}$ \\
puzzle & & & \\
\hline
\end{tabular}




\begin{tabular}{llll}
\hline $\begin{array}{l}\text { Menunjukan } \\
\text { bentuk geometri } \\
\text { pada media }\end{array}$ & & & \\
puzzle & & & \\
\hline $\begin{array}{l}\text { Menyusun } \\
\text { kepingan puzzle } \\
\text { bentuk gemetri }\end{array}$ & & & \\
\hline $\begin{array}{l}\text { Menyebutkan } \\
\text { benda - benda }\end{array}$ & & & \\
yang & & & \\
menyerupai & & \\
bentuk geometri \\
yang berada \\
dilingkungan \\
sekitar
\end{tabular}

$\%$.Pada aspek menunjukan bentuk geometri pada media puzzle memperoleh persentase nilai 98,21 \%.Pada aspek menyusun kepingan puzzle bentuk gemetri memperoleh persentase nilai 96,43\%. Pada aspek menyebutkan benda - benda yang menyerupai bentuk geometri yang berada dilingkungan sekitar memperoleh persentase nilai 96,43\%.Dan untuk aspek menunjukan benda - benda yang menyerupai bentuk geometri yang berada dilingkungan sekitar memperoleh persentase nilai 96,43\%.Jadi aspek yang mencapai indikator pada tindakan siklus I tidak ada, untuk nilai persentase tertinggi dari 5 aspek di atas adalah aspek menunjukan bentuk geometri pada media puzzle dengan persentase nilai 98,21\%.

Kemampuan anak pada siklus II ini sudah mulai berkembangan dengan baik, karena guru sudah mulai dekat dengan anak dan lebih banyak bercakap - cakap dengan anak. Masih sama seperti siklus I, pada siklus II juga menitikberatkan pada kemampuan anak dalam mengenal bentuk geometri dengan menggunakan media puzzle. Setelah melalui proses analisis terhadap penguasaan keterampilan tersebut, anak sudah mulai mengetahui bentuk samapi 6 bentuk ini terlihat dari anak muncul perkembangannya. Hal ini dapat dibuktikan dengan hasil kemampuan anak yang sudah berkembang dengan sangat baik.

Dengan menggunakan media puzzle dapat meningkatkan aspek kognitif khususnya dalam logis matematik yaitu kemampuan anak dalam mengenal bentuk geometri. Ada dalam Toward (2009) yang menjelaskan bahwa "anak yang berumur 5 tahun sudah dapat mengenal bentuk persegi, persegi panjang, segitiga, lingkaran, jajar genjang, trapesium dan layang - layang”.

\section{SIMPULAN DAN SARAN}

Berdasarkan analisis data dan pembahasan hasil perbaikan pembelajaran, maka dapat disimpulkan bahwa media puzzle dapat meningkatkan kemampuan mengenal bentuk geometri. Hal ini ditunjukan dengan terjadi peningkatan pada setiap siklusnya, pada siklus I yaitu $56,25 \%$. Pada tindakan siklus II $66,25 \%$ meningkat dengan adanya perbaikan sebelum melaksanakan tindakan siklus II. Pada siklus I hasil belajar kemampuan anak dalam mengenal bentuk geometri rata - rata yang diperoleh 3,72 presentase pencapaian $40,3 \%$, nilai tertinggi 5 dan nilai terendah 2,6. Hasil belajar kemampuan anak dalam mengenal bentuk geometri pada siklus II dengan rata rata yang diperoleh 4,61 presentase pencapaian $68,5 \%$, nilai tertinggi yang diperoleh anak adalah 6 dan nilai terendah yang diperoleh anak adalah 4 .

Hasil belajar kemampuan anak dalam mengenal bentuk geometri pada siklus II dengan rata - rata yang diperoleh 4,61 presentase pencapaian $68,5 \%$, nilai tertinggi 
yang dieroleh anak adalah 6 dan nilai terendah yang diperoleh anak adalah 4. Pada siklus III mengalami perubahan yang sangat tinggi, dengan rata -rata yang diperoleh 6,38 presentase pencapaian $97,1 \%$, nilai tertinggi yang diperoleh anak pada pembelajaran geometri adalah 7 dan nilai terendah yang didapat anak pada pembelajaran geometri adalah 5. Peningkatan terseebut sebelumnya sudah memperbaikan masalah yang ada pada siklus II sehingga kemampuan anak dalam mengenal bentuk geometri meningkat.

Berdasarkan dari hasil penelitian dan simpulan yang diperoleh, maka peneliti merekomendasikan beberapa saran yaitu sebagai berikut: 1) Perencanaan pembelajaran dengan menggunakan media puzzle perlu digunakan oleh guru dalam perencanaan dalam pembelajaran terutama dalam mengenal bentuk geometri. 2) Pelaksanaan pembelajaran dengan menggunakan media puzzle perlu digunakan oleh guru dalam proses pelaksanaan pembelajaran dalam mengenal bentuk geometri. 3) Peningkatan kemampuan mengenal bentuk geometri perlu dilakukan untuk menjadikan anak lebih mampu mengenal bentuk geometri.

\section{DAFTAR PUSTAKA}

Arikunto, Suharsimi. 2010. Prosedur Penelitian Suatu Pendekatan Praktek. Jakarta: Rineka Cipta.

Beaty, Janice J. 2013. Observasi Perkembangan Anak Usia Dini. Jakarta: Kencana.

Latif, Mukhtar, dkk. 2013. Orientasi Baru Pendidikan Anak Usia Dini. Jakarta: Kencana. Muslich, Mansur. 2014. Melaksanakan PTK itu Mudah. Jakarta: PT. Bumi Aksara.

Sari, K. (2014). Pengaruh media puzzle terhadap kemampuan anak mengenal bentuk geometri kelompok a di tk aneka ria. e-Journal PG-PAUD Universitas Negeri Surabaya,3 (1), hlm.6.

Srinigsih, Nining. 2009. Pembelajaran Matematika Terpadu untuk Anak Usia Dini. Bandung: Pustaka Sebelas.
Srianis, K. (2014). Penerapan metode bermain puzzle geometri untuk meningkatkan perkembangan kognitif anak dalam mengenal bentuk. e-Journal $P G$ PAUD Universitas Pendidikan Ganesha, 2 (1), hlm.5.

Sujiono, Yuliani Nurani. 2009. Konsep Dasar Pendidikan Anak Usia Dini. Jakarta: PT Indeks.

Toward, Paths, dkk. 2009. Mathematics Learning in Early Childhood. Washington: National Research Council.

Undang-undang UU Nomor 137 Tahun 2014 tentang Sistem Pendidikan Nasiona 